\title{
Assessment of Uses Antibiotic Residues Consumed in Khartoum State, Sudan
}

\author{
Mohamed Ismail Mohamed Fangama ${ }^{1 *}$, Mohammed Abdel Salam Abdalla ${ }^{2}$ and \\ Ismail Mohamed Fangama ${ }^{3}$
}

\author{
${ }^{I}$ Ministry of Health, Qatar Public Health Department, ${ }^{2}$ College of Veterinary Medicine \\ (SUST), ${ }^{3}$ College of Forestry and Range Science (SUST)
}

*Corresponding author

\section{Keywords}

Antibiotics,

Chlorinfrinfenicol, Oxytetracycline,

Quinolone and Sulphonamide

Article Info

Accepted:

07 December 2018

Available Online:

10 January 2019

\section{A B S T R A C T}

The study was aimed to assess the uses of antibiotic residues consumed in Khartoum State; Sudan. The problem of the study is the usage of antibiotics to food producing animals for treatment, prophylaxis and as growth promoters results in deposition of their residues in various organs and tissues. These residues after consumption via meat, milk and their products may cause adverse side effect such as toxicity, bacterial resistance, allergic reactions and many different side effect may lead to death. Veterinarians daily use many kinds of antibiotics in farm animals leading to exposure to potential health hazards associated with the antibiotic misuse practices due to their ignorance of the importance of correct use of antibiotics including the overdoses, extra label and application through un trained staff (farm worker). For data collection a questionnaire with some questions directed to the veterinarians and 25 veterinarians were randomly chosen. Also interviews were carried out with the official staff to know the different risks associated with the presence of antibiotic residues. The data were analyzed by Statistical Package of Social Science (SPSS) software. The result showed that, $60 \%$ of veterinarians give tips to the owners about the withdrawal period and $60 \%$ of them did not adhere to dosage in the prescription. On the other hand $92 \%$ of antibiotics administration follow-up is done by the owners and workers while $20 \%$ of the owners were adhered with the guidelines, and $8 \%$ of the veterinarians were continued the treatment by their self. The Oxytetracycline group, represent about $72 \%$ of antibiotics groups used for the animals treatment. The study recommended that veterinarians and owners should be aware, to control the withdrawal period and misuse of antibiotics, and finally using the law and legalization to avoid the side effect on livestock and human.

\section{Introduction}

Antibiotics residue is the one of hazards make bad effect in human and animal's body. Unfortunately many studies conducted some reports about the contamination level of the residues in human food. Fathalrhman et al., (2016), reported that, the gentamicin residues were $(25 \%)$ in raw milk samples. Mohammed (2015) in Gaza reported out of 95 positive 
results, aminoglycosides group was defined in 26 samples (27.36\%). Also Ramatla et al., (2017) reported that $8 \%$ of Sulphonamide group were represent the regular consumption in his research and the detection was $25.3 \%$. There is a study conducted by (Hakem et al., 2013), mentioned that most of positive samples cases were found contaminated by $\beta$ lactams and/or tetracyclines is $75.81 \%$ of the samples. In contrast, the macrolides and/or $\beta$ lactams and sulfonamides were recorded only in $44.35 \%$ and $36.29 \%$ respectively.

Silfrany et al., (2013) explained that quinolone withdrawal practices are not being followed properly in the area from which positive samples were obtained. In Nigeria (Wageh, 2013) make a survey on the poultry farms, he founded the chloramphenicols veterinary preparations in 21 farm authorities were $(20.0 \%)$ admitted the use.

Also in a close study conducted by (Addisalem and Bayleyegn, 2012) and (Nonga et al., 2013), in Ethiopia and in Tanzania the Oxytetracycline residues in beef samples represent about $72 \%$ of antibiotics groups used for the animals treatment. In Northern Ireland analyzed feedstuffs, to detect the contamination level, chlortetracycline were detected in $50 \%$ of the samples (Lynas et al., 1998) as growth promotor.

The antibiotic abuse is one or perhaps the most important cause of the high prevalence of drugs residues and resistance among bacteria (Zuber et al., (2012). Sawant et al., (2005) reported that in $93 \%$ of the farms, the owners administered antibiotics and untrained personnel. And regarding to (Katakweba et al., 2012), about $70 \%$ of dairy farm owners give the drugs to their animal by their selves.

The tip to the owners is very important to avoid the overdoses and extra-label uses for the antibiotics and the owners must be award and follow the advices. Fathalrhman et al., (2016) revealed that $43.3 \%$ of the veterinarians at veterinary pharmacies practice whole sale of antibiotics to the dairy farms' owners, $60 \%$ guide them to restrict dose, $73.3 \%$ advice the owners about the routes of administration.

There is many technique for antibiotics residues detection, screening same as inhibition test and the famous confirmatory techniques used for detection and analysis of drug residues same as ELISA, HPLC, liquid chromatography, gas chromatography and paper chromatography (Nisha,2008).

\section{Research objectives}

The research objectives consist of the following:

To assess the uses of antibiotic residues consumed in Khartoum state, Sudan.

To know the Veterinarian awareness towards antibiotics residues.

\section{Materials and Methods}

\section{Study area}

Khartoum state; is the national capital and the largest city of Sudan it's located at the confluence of the White Nile and the blue Nile the two Niles unite to form the river Nile. The state lies between longitudes 31.5 to $34 \mathrm{E}$ and the latitude 15 to $16 \mathrm{~N}$. it consist from three city Khartoum, Khartoum north and Omdurman.

\section{Sample size}

About 25 veterinarians where selected randomly that means not all the veterinarians have the same chance for being selected and this was called Non-probability sampling methods as described by Thrusfield (2007). 


\section{Data collection tools and methods}

It was collected by using face to face interview structured questionnaire comprise of knowledge and practice of antibiotics use among veterinarians and animal owners at Khartoum state, Sudan.

\section{Data analysis}

Data was analyzed by using SPSS (statistical package for social science) version 25 by using frequencies.

\section{Results and Discussion}

\section{Owners comply with guidance's, withdrawal period and adhere}

The result showed that, $60 \%$ of veterinarian gives tips to the owners about the withdrawal period and $40 \%$ of veterinarians they did not adhere to dosage. On the other hand $56 \%$ of responders answered that the owners comply with guidelines sometimes. The questionnaire also showed that about $60 \%$ of veterinarian did not adhere to the dosage on the prescription (Table 1). These results are nearly the same as the results of (Fathalrhman et al., 2016) revealed that $43.3 \%$ of the veterinarians at veterinary pharmacies practice whole sale of antibiotics to the dairy farms' owners, $60 \%$ guide them to restrict dose, $73.3 \%$ advice the owners about the routes of administration. However, only $56.7 \%$ from all interviewed veterinarians advice the dairy farms' owners for the withdrawal period.

$84 \%$ of veterinarians answered that they don't know the suitable screening or confirmatory test for residues detection technique. This agree with (Nisha,2008) mentioned that the famous confirmatory techniques used for detection and analysis of drug residues same as ELISA,HPLC, liquid chromatography, gas chromatography and paper chromatography.

\section{Usage of antibiotics groups}

In Table 2, the Oxytetracycline group, represent about $72 \%$ of antibiotics groups used for the animals treatment. This is close to study conducted by (Addisalem and Bayleyegn, 2012) and (Nonga et al., 2013), in Ethiopia and in Tanzania OTC residues in beef samples. Also this finding was agree with (Lynas et al., 1998) in Northern Ireland analyzed feedstuffs, to detect the contamination level, chlortetracycline was detected in $50 \%$ of the samples. The results also appeared that $32 \%$ of the antibiotics used in poultry farms, lambs and calves. This results was closed to study conducted in 2006 in Venezuela reported that, of 20 samples, $50 \%$ were positive for quinolone residues that exceeded the maximum limit of residues allowed in poultry meat.

Similarly, in 2005, 23\% (3 of 13) of fish meat sampled in Chile contained antibiotic residues above the established maximum limits (3). The Iran Veterinary Organization conducted research in Teheran Province by analyzing 270 samples, and of those samples, $24(8.8 \%)$ were positive for quinolone residues (8). In Saudi Arabia, 35\% of the samples of broiler meat were positive for quinolone residues (1). The study explained that quinolone withdrawal practices are not being followed properly in the area from which positive samples were obtained (Silfrany et al., 2013).

There is a study conducted by (Hakem et al., 2013), most of positive samples cases were found contaminated by $\beta$-lactams and/or tetracyclines is $75.81 \%$. In contrast, the macrolides and/or $\beta$-lactams and sulfonamides were recorded only in $44.35 \%$ and $36.29 \%$ respectively. While, the aminoglycosides were implicated in $13.71 \%$ of positive cases (Table 2 ). The result also showed that, the usage of chloramphenicol group was $8 \%$, and this is lower than the percent mentioned by (Wageh, 
2013), In a survey of chloramphenicol use in poultry farms in Kaduna State Nigeria, 21 farm authorities $(20.0 \%)$ admitted the use of chloramphenicol as veterinary preparations (Table 2).

About the aminoglycoside uses in the daily veterinarian consumption is $4 \%$, but (Fathalrhman et al., 2016) reported that, the gentamicin residues were $(25 \%)$ in raw milk samples and (Mohammed, 2015) in Gaza reported out of 95 positive results, aminoglycosides group was defined in 26 samples (27.36\%), and Tsepo Ramatla et al., 2017 reported the streptomycin, 34\%.On the other hand Sulphonamide group were 8\% represent the regular consumption in the study but (Ramatla et al., 2017) reported that the detection was $25.3 \%$.

Table.1 Owners comply with guidance, withdrawal period and adhere

\begin{tabular}{|c|c|c|c|c|}
\hline No. & Items & Yes & No & Sometimes \\
\hline \multirow[t]{2}{*}{1} & \multirow{2}{*}{$\begin{array}{l}\text { Do you give owners ATIPS about the } \\
\text { withdrawal period }\end{array}$} & 15 & 10 & 0 \\
\hline & & 60.0 & 40.0 & 0.0 \\
\hline \multirow[t]{2}{*}{2} & \multirow[t]{2}{*}{ Do the owners comply with guidance } & 5 & 6 & 14 \\
\hline & & 20.0 & 24.0 & 56.0 \\
\hline \multirow[t]{2}{*}{3} & \multirow{2}{*}{$\begin{array}{l}\text { Do you adhere to the dosage mentioned in the } \\
\text { prescription }\end{array}$} & 6 & 15 & 4 \\
\hline & & 24.0 & 60.0 & 16.0 \\
\hline
\end{tabular}

Source: IPM SPSS 24 package

Table.2 Usage of Antibiotics

\begin{tabular}{|l|l|c|c|c|c|c|c|}
\hline No & Items & $\begin{array}{l}\text { Oxy } \\
\text { Tetracycline }\end{array}$ & $\begin{array}{l}\text { Sulpho } \\
\text { namide }\end{array}$ & $\begin{array}{l}\text { Quinol } \\
\text { ones }\end{array}$ & Chlorampenicol & Aminoglicoside & $\begin{array}{l}\text { I have } \\
\text { no idea }\end{array}$ \\
\hline $\mathbf{1}$ & $\begin{array}{l}\text { What is the most } \\
\text { Antibiotics/used in }\end{array}$ & 18 & 2 & 2 & 2 & 1 & 0 \\
\hline $\begin{array}{l}\text { your work? } \\
\mathbf{2}\end{array}$ & $\begin{array}{l}\text { What is the most } \\
\text { antibiotics used for } \\
\text { the treatment of } \\
\text { calves, LAMBS and } \\
\text { poultry in your work }\end{array}$ & 12.0 & 8.0 & 8.0 & 8.0 & 4.0 & 0.0 \\
\hline
\end{tabular}

Source: IPM SPSS 24 package

Table.3 Follow-up of antibiotics administration

\begin{tabular}{|l|c|c|}
\hline \multicolumn{1}{|c|}{ Value } & Frequencies & $\%$ \\
\hline Yes & 2 & 8.0 \\
\hline The owners / workers & 23 & 92.0 \\
\hline Total & 25 & 100.0 \\
\hline
\end{tabular}

Source: IPM SPSS 24 package 
Table 3, showed that $92 \%$ of antibiotics administration follow-up is done by the owners and workers, this may be lead to misuses or extra-liable because of $20 \%$ only of the owners they are adhere with the guidelines, and $8 \%$ of the veterinarian continue the treatment by their self. This result was agreed with (Sawant et al., 2005), reported that in $93 \%$ of the farms, the owners administered antibiotics and untrained personnel and regarding to Katakweba et al., 2012 , about $70 \%$ of dairy farm owners give the drugs to their animal. Komolafe (2003) and El Zuber et al., (2012) reported that the antibiotic abuse is one or perhaps the most important cause of the high prevalence of drugs residues and resistance among bacteria.

In conclusion, there is no doughts, the harmful effect of antibiotics residues reflect on the human and animal's health. The side effect should be avoided by treating the causes of this problem and to start from veterinarians and owners awareness, to control the withdrawal period and misuse of antibiotics, and finally using the law and legalization to avoid the side effect on livestock and human.

\section{References}

Bayarski, Y. (2006). Antibiotics and Their Types, Uses and Side Effects. Retrieved from http://ezinearticles. com.

Cerniglia, C. E., and Kotarski, S. (1999). Evaluation of veterinary drug residues in food for their potential to affect human intestinal microflora. Regulatory Toxicology and Pharmacology, 29(3), 238-261.

El Zubeir, I.E.M., Kiessling, S., Kutzer, P., Wieler, L.H. and ElOwni, O.A.O. (2012). Characterization of tetracycline resistant Staphylococcus aureus isolated from bovine mastitis in Khartoum State, Sudan. University of Khart. J. Vet.
Med. and Anim. Prod., 3 (2): 53-64.

Fathalrhman, A. N., Osman, A. A. A., Idres, M. A., and Sid-Ahmed, M. A. (2016). Autonomous Navigation in Dynamic Environments (Doctoral dissertation, Sudan University of Science and Technology).

Hakem et al.,(2013). Hakem, A., Titouche, Y., Houali, K., Yabrir, B., Malki, O., Chenouf, N., Yahiaoui, S., Labiad, M., Ghenim, H., Kechih-Bounar, S., Chirilă, F., Lapusan, A., Fiţ, N.I. Screening of Antibiotics Residues in Poultry Meat by Microbiological Methods. Bull. University of Agricultural Sciences and Veterinary Medicine, Veterinary Medicine 2013, 70(1), 77-82.

Komolafe, O. O. (2003). Antibiotic resistance in bacteria-an emerging public health problem. Malawi Medical Journal, 15(2), 63-67.

Lynas, L., Currie, D., McCaughey, W. J., McEvoy, J. D., and Kennedy, D. G. (1998). Contamination of animal feeding stuffs with undeclared antimicrobial additives. Food Additives and Contaminants, 15(2), 162-170.

Mohammed A. Albayoumi (2015). Detection of Antibiotic Residues in Broiler Chickens in Gaza Strip. May 2015

Nonga, H. E., Sungura, K. H., and Ngowi, H. A. (2013). Assessment of veterinary drug use and determination of antimicrobial residues in broiler chicken meat in Urban district, Zanzibar, Tanzania.

Ramatla, T., Ngoma, L., Adetunji, M., and Mwanza, M. (2017). Evaluation of Antibiotic Residues in Raw Meat Using Different Analytical Methods. Antibiotics, 6(4), 34.

Sawant, A. A., Sordillo, L. M., and Jayarao, B. M. (2005). A survey on antibiotic usage in dairy herds in Pennsylvania. Journal of Dairy Science, 88(8), 29912999. 
Silfrany, R. O., Caba, R. E., de Los Santos, F. S., and Hanning, I. (2013). Detection of quinolones in poultry meat obtained from retail centers in Santiago Province, the Dominican Republic. Journal of food protection, 76(2), 352-354.

Thrusfield, M. (2007) Veterinary Epidemiology. 3rd ed., Ch. 13. Black
Well Science Ltd., United Kingdom. Pp. 228-246.

Wageh SD, Elsaid AE, Mohamed TE, Yoshinori ISN, Mayumi I (2013). Antibiotic residues in food: the African scenario Japanese Journal of Veterinary Research, 61: 13-22.

\section{How to cite this article:}

Mohamed Ismail Mohamed Fangama, Mohammed Abdel Salam Abdalla and Ismail Mohamed Fangama. 2019. Assessment of Uses Antibiotic Residues Consumed in Khartoum State, Sudan. Int.J.Curr.Microbiol.App.Sci. 8(01): 898-903. doi: https://doi.org/10.20546/ijcmas.2019.801.097 